\title{
ANALYSIS OF TRANSIENT HISTORY OF UNDERGROUND EXCAVATIONS FOR RADIOACTIVE WASTE ISOLATION
}

\author{
J. Ratigan \\ L. Van Sambeek \\ RE/SPEC Inc. \\ Rapid City, South Dakota 57709
}

August 1977

This paper was prepared for publication in the Proceedings of "Rock Store-77," a conference held in Stockholm, Sweden, in September 1977. It was prepared by RE/SPEC Inc. under subcontract 89Y-22303 with Union Carbide Corporation, Nuclear Division. The subcontract was administered by the Office of Waste Isolation

prepared for the U.S. ENERGY RESEARCH AND DEVELOPMENT ADMINISTRATION under U.S. GOVERNMENT Contract W-7405 eng 26 


\section{DISCLAIMER}

This report was prepared as an account of work sponsored by an agency of the United States Government. Neither the United States Government nor any agency Thereof, nor any of their employees, makes any warranty, express or implied, or assumes any legal liability or responsibility for the accuracy, completeness, or usefulness of any information, apparatus, product, or process disclosed, or represents that its use would not infringe privately owned rights. Reference herein to any specific commercial product, process, or service by trade name, trademark, manufacturer, or otherwise does not necessarily constitute or imply its endorsement, recommendation, or favoring by the United States Government or any agency thereof. The views and opinions of authors expressed herein do not necessarily state or reflect those of the United States Government or any agency thereof. 


\section{DISCLAIMER}

Portions of this document may be illegible in electronic image products. Images are produced from the best available original document. 
This report was prepared as an account of work sponsored by the United States Government. Neither the United States nor the Energy Research and Development Administration, nor any of their employees, nor any of their contractors, subcontractors, or their employees, makes any warranty, express or implied, or assumes any legal liability or responsibility for the accuracy, completeness or usefulness of any information, apparatus, product or process disclosed, or represents that its use would not infringe privately owned rights. 
J. Ratigan, 2. Van Sambeek

RE/SPEC INC, Rapid City, SD, USA

Analysic of cransient thermal history of underground excavations for radioactive waste "isolation

ALLLYSIS OF TRASIENT THEPALL HISTORY OF UNDERGROWD EXCAVATIOAS FOR PADIOACTIVE WASTE ISOLATIOU

J. RATIGAN - RE/SPEC INC, RAPID CITY, SD, USA

L. VAN SABBEE, RE/SPEC INC, RAPID CITY, SD, USA

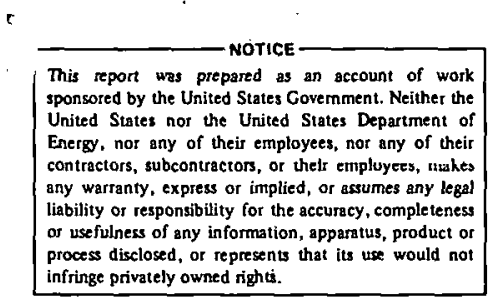

The constraints and phenomena which must be modeled in realizing a rational prediction of temperature history in a radioactive waste repository are presented. The effects of conductive and radistive heat transfer between the waste package and host rock are presented. Resulta of numerical investigations are utilized to present specific gicuations wherein analytical approximations to the waste caniazer geometry way be wilized. The paper also presents the results of approximations to the mean underground repository temperatures. The reliability of both methods of predicting temperatures lo assessed through the campariBon of predicted cemperatures with measured temperatures frod the Project Salt Vault field experiment. The design of experitients for wodel verification is discussed and a specific heater experiment which has been proposed is presented.

Les constraints et les phénoménes, qu'il faut modeler pour produire une piédiction rationelle de la temperature progressive dans un stockage de déchets radioactifs, sout discutées. Les effets de la transaission de la chaleur. par conductibilice et par rayonnement de la caisse de ces dechets $a$ la roche qui l'environne, sont présentés. Des résultato des recherches numériguea sont utilisées pour décrire des cas specifiques dana lesquels des approximations analytiques de la forme de la caisse dę déchets sont convenables. En plus, les résultats des approximations des temperatures souterraines due stockage sont décrites. La précision relative des deux mêthodes de la prédiction des tewpératures prédices en comparasion des températures ráalisée en cours de l'expèrience Project Salt Vaulc. Le développtrent des expérience specifique d"appareil de chauffage qu'on a proposée est décrice.

Die zuänge und Phänomene, die bei Verwirklichung einer rationalen Voraussage der Temperaturgeschichre in einer radioaktiven MUll ablage modelliert Uërden mussen, veroen dusgelegt. Bie Hiskugíl von loitondar und strahlender wirmeübertragung zwischen dew Abfallpaket und des Aufnahaegestein verden aufgezeigt, Ergebnisae von zahlenäbigen Untersuchungen verden benutzt, um spezifische Situationen darzulegen, in denen analytische Annäherungen an die Abfallkanistergeometrie eusgenutzt verden können. Der Vortrag behandelr auch die Ergebnisse von Annäheruratn an die mitcleren Temperaturen unterirdischer Ablapen. Die zuverlïasigkeit der Methode des Vorhersagens von Iemperaturen wird Jurch einen Vergleich von vorherresagten mit Remessenen

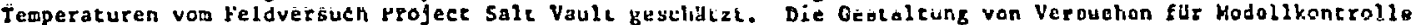
vird erörtert, und es wird ein vorgeschlagener opezifischer Erhifzerversuch erklärc.

\section{INTRODUCTION}

The explacement of radioactive wastes into underground excavacions zesults in theroomechanical design problems not generally encountered in normal rock excavation operations. The requirement that the geological formation must contain the waste for up to hundreds of thousands of years necessitates the utilization of unprecedented site recognizance, zock properties resting and mathematical modeling in order to design a repository vich a high assurance of long term vaste containment. The resting of any wathematical method used in predicting the formation response to the radiogenic heat input is an essential segaent of the repository design, since real time experience will not conclusively establish the long term rock response. Therefore, the real time experiments should be utilized co rest a prior mathematical predictions of rock response.

In formulating a wathematical model for the prediction of ter-perature fields occurring in a reposicory after emplaccment of heat generating uste. one shuld be cognizane of what physical
Bituations must be modeled and to what degree of accuracy the modeling need be extended. The modeling accuracy in a material or geometric area must be correlated to the degree of accuracy that cen be had in determining the waterial response in the laboratory and in the field, and the geometric accuracy which can be obcained in practice. Previ. ous investigations have illustrated the concept of using only as sophisticated mathemaclcal modeliug as is justified by the geometric and material properties input data. When the repository site and material properties vere fairly vell defined, Cheverton and Turnet (1972) utifized a numerical method to predict the temperatures in a specific method to predict the temperatures in a specific which due to other.ongoing studies, they vere able to vary in optimizing the waste package density subject to several maxinum teepersture criterion. In other investigations in which the geometry of the reposacosy and the materials properties were merely bounded over a wide range (Hucti. 1971; Ratigan, et.al.. 1976; Schmeicier and Plate, 1974) 
less expensive analytical methods for predicting cemperature fields vere employed.

The intent of this paper is to delineate the important geometric and rock properties of a repository aice which should be modeled in obtaining rational prediction of temperature fields arising due to the euplacement of heat generacing waste. In this regard the assunptions, methodology and resulte vill be presented for a variety of investigations concerned with the prediction of boch near field temperatures and far field tenperatures. In utilizing the resules of previous investigations, the adequacy of econorical analytical methods will be assessed. A currently proposed field heater experiment and a description of the mathemarical modeling utilized in the design will be presented.

\section{WASTE AND SITE CMURACTERIZATION}

As far as prediction of thermal history of a reposicory concaining heat generating wastes, on is Benerally concerned with either of two types of vaste; reprocessed (high level vaste) or unreprocessed (spent fuel). Figure 1 presents a comparison of rypical tranaient heat generation for high level waste and spent fuel. The particular characterization of the curves depends on the type of reactor, time of repocessing, etc. How ever, the curves are typical for a comercial PWR and are sufficient in displaying the narked difference between the heat dissipation of high level vaste and spent fuel.

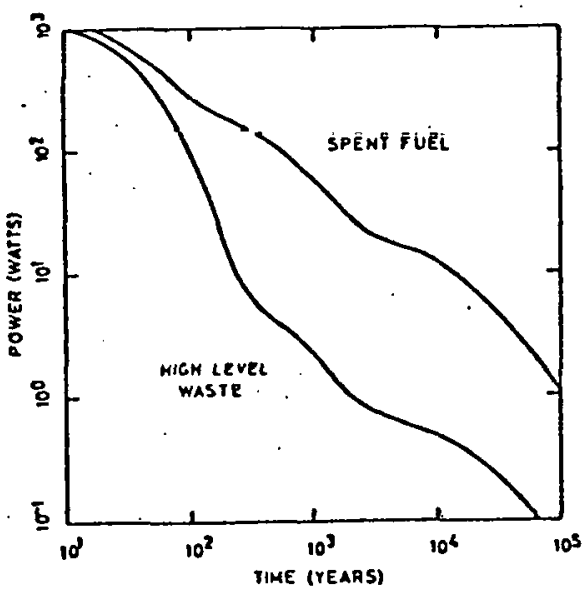

Figure 1. Transient Heat Ceneration for High Level Haste and Spent Fuel (Per Metric Ton Heavy Metal)

Due to the heat generating differences between high level waste and spent fuel, temperature predictions for a high level waste repository are dictions for a high level waste repository are very short period of tithe, say 10-30 years.

Previous investigations of temperature history have for the most part been performed with typical scratigraphic coluturs, propereics of which have been usually taken from the literatuie. Excep" cions exist to this statement uhich are fortunately increasing as time goes on. To the outhors' knowledge all prevlous detailed atudies have also only included the conductive heat transfer in the rock mass. Cheverton and Turner (1973) state that the forced convection heat cransfer which occurs in aquifers above salt depostto containing a repository can be treated in a separate analysis due to Ito expected low signiflcanco. However, in a nonGalt mass such a cryatalline rock, the heat transfer mechanisms of tree and forced convection may be of aignificance. Tresently, studies of the importance of free and forced convective heat iransfer are being performed in Sweden (Lindblom, et.al.. 1977).

In previous analyses of temperature history in repositories the domain of analysis has usually been divided into two regions; near field and far field. The near field analysis is generally concerned with the waste package, near rock temperature history and the temperature fields arising in the repository otructurals (pillars, roof, floor). The near field predictions are essential in determining rock mass response which will dictate storage room support requirements and potential waste package dawage. The near field temperature history is also important in assessing waste package corrosion, waste package retrievability and ventilation requirements.

Far field temperature predictions are utilized to analyze the gross movement of the geological formacion. the remperature $r$ ise In potential aquifers and the cemperature perturbation of the biosphere.

The near field temperature history is most dependent upon

\section{- Emplacement ocheme \\ n Parkagelrnrk interface \\ - Rock mass thermal properties}

The emplacement schemes referred to in this paper are generally centered around the roow floor drillhole concept (Bradshaw and McClain, 1971). However. studies by several investigators have indicated that other emplacement methods may show some merit.

The package/rock interface has been an area of cunsiderable study over the past decade. The type of backfill (if any) used between the package and the drill-hole periphery hos a significant influence on package retrievability and containment.

Since the rock mass is being utilized as a heat sink for the radiogenic hest dissipation, the thermal properties of the site rock are of particular importance in determining the near field temperature response. The themal conductivity and diffusivity of the site rock are directly related to the maximum temperatures occurring in the near field and al so to the times at which these maxirsums occur. In addition to the thermal conductivity and diffusivity of the bite rock, the convective film coefficient an the excavation floor can play a major role in deterwining the heat loss to the repository ventilation. Additionally, any "coupled" rock nias 3 responses in water bearing aite rocks, such as perreability changes with temperature and stress ma provide a wajur influence in the near fiold temperature history. 
If an emplacement scheme which utilizes a laree quarity of backfill, material is cmployed, such as emplacement on the storage room floors, the neat field temperature magnitude and transient history is highly dependent upon the backfill thermal properties.

Far field temperatures are most significantly influenced by waste type, repository depth and site rock themal properties. Since the majority of the energy released by the waste will be initially cransferred to the geological formation, a higher energy infut (such as the case with spent fuel) vill result in high temperatures which reside in the rock mass for long periods of time. The depch of the repository will dictate length of the path to the atmosphere and to some extent the amount of rock which will be available to receive the energy given off by the waste.

\section{NEAR FIELD TEMPERATURE HISTORY}

In the analysis of near field cemperature history the four major areas which should be modeled are

- Waste package

- Waste package/rock incerface

- Rock mass

- Repository ventilation

The thermal properties of the waste package are dependent upon the waste type and the material used in solidification, if reprocessing is being utilized. The rock near field. cemperatures ace, however, only slightly influenced by a change in waste themal properties, since the waste generally encompasses such a sinall volume. The waste packaging (usually assumed metallic) has an extremely low cemperature gradient due to the large values of conductivicy for metallic materials. It is cherefore, usually, assumed that the packaging temperature is approximately. equal to the cemperature on the outer periphery of the waste.

The waste package/tock iuterface modeling accuracy is dependent upon several variables. If one is concerned with the temperatures in the rock mass, the interface can be assumed to be conductive. If one is more concerned with waste package temperature history, the additional heat transfer modes of convection and radiation could possibly play a role if the interface is large and contains no backfill, e.g., an air gap.

Figure 2 presents the results obtained by Callahan, et. al.,(1975), in the analysig of the. importance of the radiative heat transfer at the waste rock interface through the use of finite elements. In this scudy the waste package was taken to be a cylinder $.27 \mathrm{~m}$ in diamecer and $3 \mathrm{~m}$ in length. The air gap was taken to $9 \mathrm{~cm}$ and the rock mass was bedded salt. Allowing radiative heat transfer at clic inceface resulte in assontially the same temperacures in the salt mass as when assuming merely conduclive heat cransfer. However, the temperatures whrnin clie tasle pakase are eignificatiy alcered by assuming the radiacive mode. Subsequent package corrosion stedies would obviously be significanty altered.

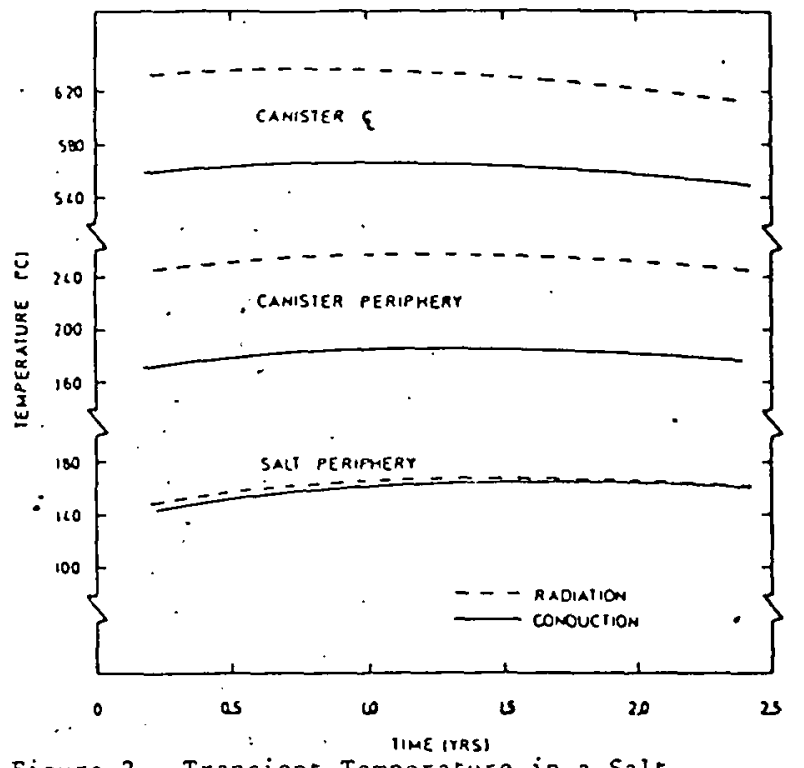

Figure 2. Transient Temperature in a Salt Reposicory Model for Radiative and Conductive Interfaces.

In the specific coricept discussed by Callahan, et. al., (1975), one is forced to accept the higher wasce cemperatures which result from leaving an air - aj or to accept. the possibility of salt brine coming inco imediate contact with the package if an air gap is not present. The actural heat transfer mechanisms which occur at the waste package/rock interface are of such importance in determining waste temperature history that in situ heacer experiments have been and will be performed (Carter. e.al., 1977), in order to decermine the actual mechanisms occurting at the interface. One $n^{\prime \prime}$ these experimencs will be discussed later:

When one assumes only conductive heat transfer at the package/rock interface, the tenperature history. in the very near field lock can be easily assessed in terms of site rock thermal characteristics. Rafigan (1976) has shown that the temperature hiscory in the very near field rcck around a cylindrical waste packaze can be presented in a non-dimensional fashion by utilizing the Fourier number and che variables comprising the temperature dimension arising from the solution of a line heat source in an infinite medium. These results are for short periods of time and do not include any heat. generation decay of the waste. However, a similar correlation for long periods of time could be obrained by comparing the solution of a decaying heat generating line in a finite medium given by Bradshaw, et. al. (1970), with the finite element model of Ratigan assuning. a representative heat decay, such as those given in Figure 1 .

One of the major variables affecting the temperarure history in the storage room structurals is the ventilation period after emplacement. For a vidp range of Nusselt numbers (Lindblom, et.al.. $1977)$ the presence of ventilation results in a significant reduction in storage room temperatures. In general, with a reasonable amount of ventilation, approximately one-half of the generated heat can be removed by the mine air during the period of ventilation, depending on waste age, ventilation system, etc. 
3. Ratigun, L. Van Sambeek

RE/SPEC INC, Rapid City, SD, USA

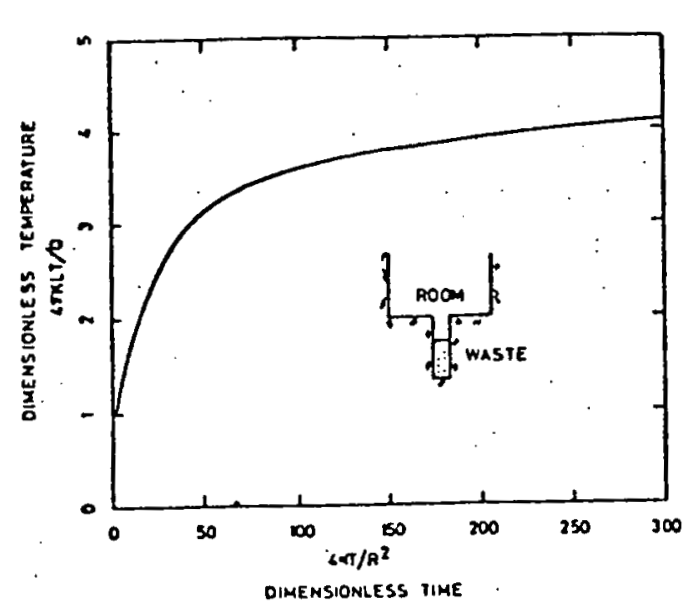

Figure 3. Non-Dimensional Temperature at the Haste/Rock Incerface as a Function of the Fourier Number.

While the rajority of the previous investigations have been performed through the use of numerical wethods (finite difference and finite elenent) several studies have been performed wich otrictly analyeical wethods which have provided insight into che effects of rock thermal propercies, package spacing and repository depth in a very econonical fashion.

\section{FAR FIELD TEIQEERATURE HISTORY}

In predicting the far field temperature history of a rock mass containing a repository, one need only wodel the repository as a heat generating medium vithin the rock wass. Discrece modeling of the repository vill be relarively adequate for large one level. This type of wodel has been used pteviously (Cheverton and Turner, 1972; Callahan, et.al. 1977). In the far field analysis the stratigraphic 1977). In the far field analysis the stratigraphic ing than was the case in the near fieid analysis.

The initial geothermal ceoperature gradient is important in the rathenatical model if temperature depensent material properties are to be exployed. However, if all theral properties are taken to be constant, the initial teaperature state can be superposed on the temperature rises due to the heat generstion to arrive at the absolute temperatures. In a far fiold analysis the model nust be of such a large domain that it vill naturally include the earchs burface. The choice of boundary condition at the esrth's surface vill usually be either constont teoperacure or convective. For modest values of thermal flux or gross thermal loading (CTL) both boundary condicions result in very similar temperature fie:ds ior the majority of the rock mass. However, for shallow depths, or low Nussele nuebers, the choice of the boundary condition can resule in different temperatures for a large portion of the rock.
Previous investigations have assumed only conductive heat transfer in the rock mass and os previously stated, this approsch is adequate with salt masses. Hovever, forced and free convective cransfer modes way play a significant role in vater bearing crystelline rock mases.

In predicting the far field temperature hlstory around a repository the waste typo is an extremely important variahle. The energy which is produced by spent fuel emplacement is so much greater than that for high level waste that temperacures throughout clie geological structure are sustained at rejacively high levels for extended periods of time. For a specific bedded salt repository analyzed by Callahab. et.al.. (1977) the repository centerline temperacures for high level waste and spent fuel varied oignificantly a function of time (see figure 4). These repositories had initial C.T.L. values of $150,75,50$, and $25 \mathrm{kw} / \mathrm{ac}$ re and the vaste was asiured to be 10 years old upon emplacement. Younger vaste has o tendency to peak at a higher valuc and at an earlier time, wheress an older waste has a tendency to peok lower at a later time.

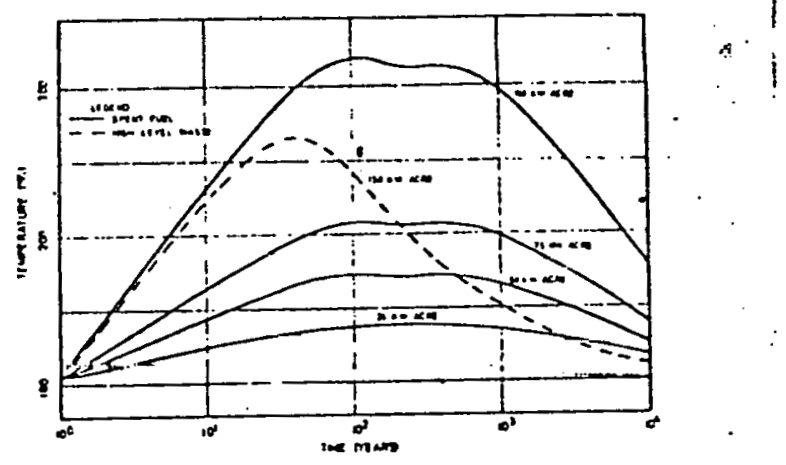

Figure 4. Comparison of Repository Cencerliue Tenperatures for Spent Fuel and $\mathrm{High}$ Level Hagte

As an illuatration of the power of analytical thetlods in the prediction of cransient temperatures, figure 5 presents a comparison of the finite element resulta obtained by Callahan with the temperature history predicred by assuming a plate in an infinite medium predicted hest representative of 10 year old spent generating heat representative of fol conaista of fuel. The representation of the fuel consists of ferent half lives (Rorigan, 1977). Also presented in Figure 5 are the analytical predicted temperatures resulting from the addition of ventilation and the resulting from the adent pectentage of heat dissipated thruugh the repository ventilation. The analytical solution assumes conscant. ventilation with time and as buch is surieuhat unrealistic for times greater than, say 30 years. However, Ratigan (2977) has presented the 30 years. However, Ratigan (2977) has presenced analytical solution for discrete-time-ventilation is felt by the rock at the widplane of the reposicory for almost an order of magnitude longer, e.8., if ventilation oceurs for 30 years the tamperatures in ve midplane are alcered for almost 300 years. 


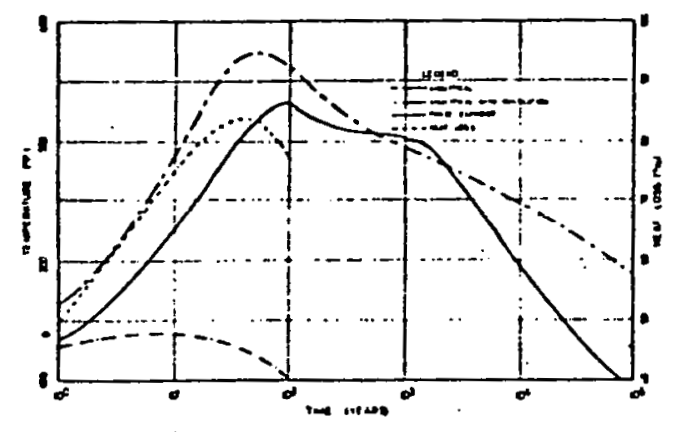

Figure S. Comparison of Finite Element and Analytical Temperatures for a Spent Fuel Reposicory.

The analytical plane source solution has the distinct advantage of being able to predict che maximum temperature rise and the time of occurrance as a function of the waste parameters, bite rock characteristics and repository depth.

COMPARISON OF METHEMATICAL MODELS AND FIELD RESIRLTS

No mathematical model, analytical or numerical is of any value in predicting rock response for subsequenc repository design unless the model eccuratly represents the physical occurrences in the actual repository. For this reason, the models shouid be utilized in predicting a prluel clie rock nass response in typical repository sicuations in order to validace the models worthinesa. Since $f$ ield level experiments are expensive to perforn, post facto predictions have been utilized to evaluate the predictive capability of numerical methods for temperacure histosy calculationa. Future efforts vill emeompass not only post facto predictions but lso a priori predictions of typical repository siruacions (Van Sambeek. 1976).

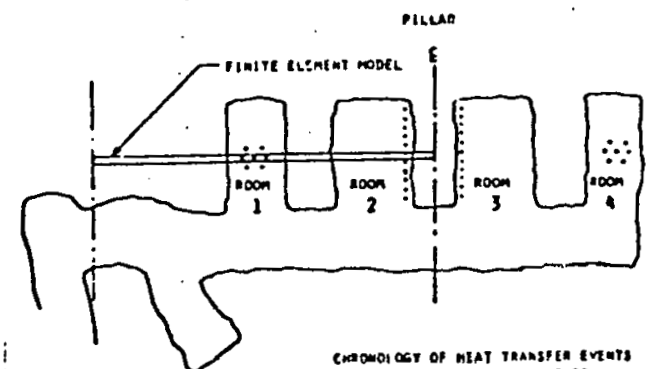

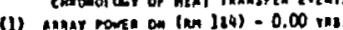

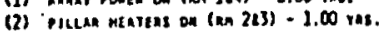

(3) Merar rank wont - 1.20 ves.

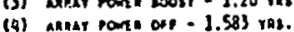

(5) Prelan matcas ofl - 1.90 ves.

Figure 6. Plan and Power Chronology for Project Salt Vaule
As regards post facto predictions, the Project Salt Voult (PSV) (Bradshaw and McClain, 1971), experiment performed at Lyons, Kansas, USA, has been utilized for numerical model verification. The major part of the experiment was perforwed in four rooms as shown in Figure 6: Rooms 1 and 4 contain 2 Iong hesters placed in an array with a widplane depth of $3 \mathrm{~m}$. Rooms 2 - 3 contained 2 in heacers spaced obout pillar 2 - 3 with a midplane depth of $3 \mathrm{~m}$. The sequence for heater control is given in Figure 6 in terms of at andard years.
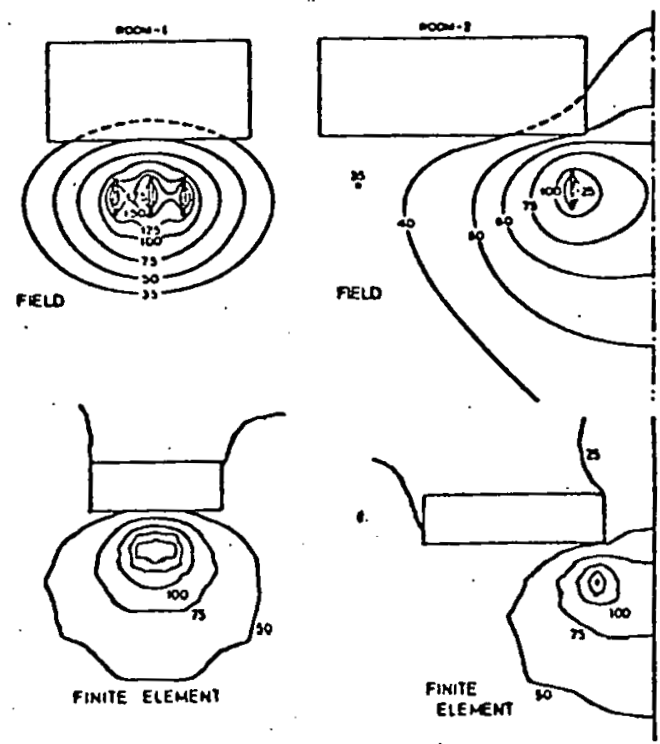

Figure 7. Finite Element and Pield Measured Maximu Temperatures for Project Salt Vault.

In modeling the PSV experiment a two-dimensional finite elcment modal throubh the center portion of the experimental area was constructed. The external vertical boundaries of the model vere caken at the cencer of pillar 2 - 3 and the barrier pillar west of room 1. The model was analyzed for several value of thermal conductivity. The mine ventila$t$ ion was also modeled. The power-time characteriatics of the experiment vere also modeled with the exception that dinor power failuresvere not accounted for. The results of the simulation given by Ratigan (1976) are very encouraging. As displayed in Figure 7. the temperature contours of maximum temperature as predicted by the finite element model are very similar to the experimentally deterwined values at most locations. Rarigan (1976) has also utilized a superposed array of point heat cources co predict the temperatures in Room 1 at a depth of $3 \mathrm{~m}$. Thess resulcs are presented in Figure 8 . The comparison is not totally valid as the point heat source solution does not represent the array power boost, e.g., the power for the point source solution is constant at the boostad power level. 


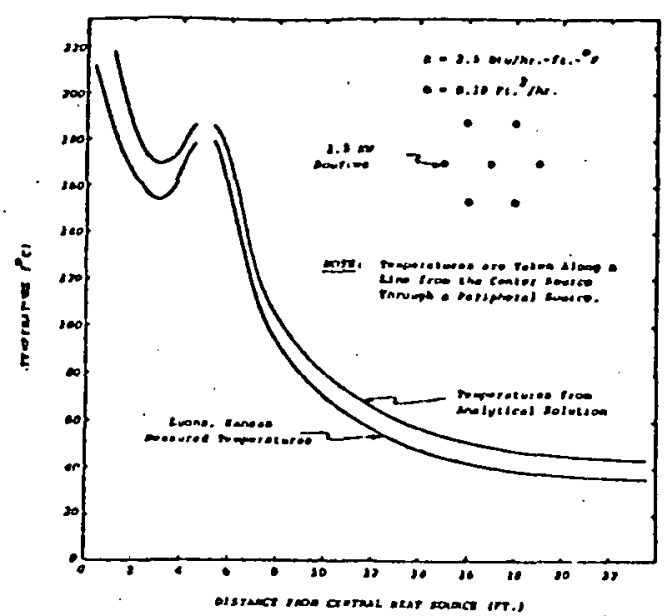

Figure 8. Analytical and Field Measured Maxinum Temperatures in Project Salt Vault

\section{IN SITU HEATER EXPERIMENT}

In an effort co validate the methods for predicting rock mass response to repository situations and to assess the difference betueen dome and bedded salt response, the Energy and Development Research Administration Office of Waste Isolation, Oak Ridge National Laboratory, Oak Ridge, Tennessee, USA, has initiated plans for an in situ heater experimant in bume salt. The 2 ayouc of clie expectuentix wlll be briefly described and the prelininary thermal calculations discussed. The experiment vill involve three distinct heater experiments combining different backfill eacerial and peripheral heatera. A plan vieu typical metober of the cotal heacer experiwent io ohom in Figura 9. Tho inctrumentstion shown in the figure is not complete, however some of the major components are displayed. The posi-. lionling of the scress and temperature measuring instrumentation is extremely important in order that all significant events may be monitored. In the initial design of the instrumentation plan, superposed point heat sources vere utilized to position the instrumentation appropriately (Van Sambeek, 1976). Based on the success of the point source solution in the prediction of PSV temperatures. The polnt cource bolution vas again utilized in the preliminary experimenc instrumentation design. The stress and deformation instrumentation is directly correlated to the tenperatute instrumentation positions for obvious reasons. The proposed experiment vill be utilized for many purposes other than merely temperature monitoring. The therromechanical response of salt, which is wuch more complicated than the thermal response, will be continually monitored. A priori predictions of the rock mass response will be perforwed throughout this calendar year and the results of the experiment will be utilized to assess the relative worth of the predictive methodo.

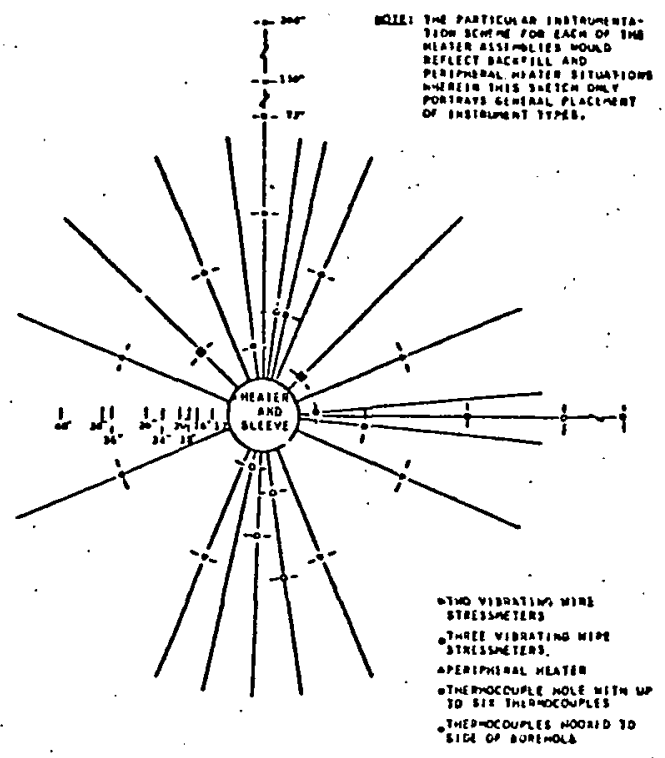

Figure 9. Plan View of a Typical Member of . .... Proposed Heater Experiment

\section{ACKNOLLEDGHENT}

This research wa performed under a subcontract with Union Carbide Corporation, Nuclear Division. under subcontract with. She U.S. Energy Research a1!d Administration. The subcontract was aduiuistered by Union Carbide's office of Waste lsolation. The authors are indebted to Hagconsult $A B$, Stockholm, Sueden, for assistance in the preparation of the manuscripe. The views and conclusions contained in this paper are those of the authors and should not be interpreted os necessarlily representing the official policies or reconnendations of the office of Waste Isolation, or Union Carbide Corporation, Nuclesr Division, or the U.S. Energy Research and Development Administration.

\section{REFERENCES}

BRADSHAH, R. L. and McCLAIN, H.C., editors, 1971, Project Salt Vault: A Demonstration of the Disposal of High-Activity Solidified Wastes in Underground Salt Mines, ORNL-4555.

BRADSHAW, R.L., PERONA, J.J., BLOMEKE, J.O., and BOECLY, H.J., Jr.. 1969, Evaluation of Ultimate Disposal Mechoda for Liquid and Solid Radiosetive Waster VI. Disposal of Solid Waste in Salt Formations, ORNL-3358 (Rev.)

CALLAHAN, C.D. RATIGAN, J.L., RUSSELL, J.E, and FOSSUM, A.F., 1975, Heat Transfer Analyais of the Waste-Container Sleeve/Salt Configuration, ORH.Sub-4269-7.

CALLAHAN, C.D. and RATICAN, J.L., April, 1977. Themolascic Aralysey of 3petit Tuel Repuoitorics in Bedded and Dome Salt, subritted to Uffice of Huste Isolation, Oak Ridge, Tennessee. 
J. Ratigan, L. Van Sambeek

RE/SPEC INC, Rapid City, SO, USA

CARTER, N.L., GOODMAN, R.E., and MERRILL, R.H.

February, 1977, Rock Mechanics Review/Workshop on Radioactive Haste Material, submitted to the Office of Waste Isolation, ORNL.

CHEVERTON, R.D. and TURNER, H.D., 1972, Thermal Analysis of the National Radioactive Repositoryi Progress chrougli Matich, 1972, ONL-4729.

CHEVERTON, R.D., and TURNER, H.D., 1973, Themial Considerations and Analysis for a Radioactive Waste Repository, Nuclear Technology, Vol. 19, pp, 21-33.

I.INDBLOM, W.E., GNIRK, P.F., CHARLWOOD, R.G. and CHERRY, J., 1977, Groundwater Moventents Around a Repository, submitced to Kärnbränslesijkerhet, Swaden.

MUFTI, I.R., 1971, Geothermal Aspects of Radioactive Waste Disposal inco the Subsurface, Journal of Ceophysical Research, Vol. 76, No. 35, pp. 8568-8585.

RATICAN, J.L., 1976, Preliminary Analysis of the Potential for Thermally-Induced Rock Fracture Around Higli Level Waste Containers, ORNL-Sub-4269-20.

RITICAN, J.L., CHARLWOOD, R,G., and SKIBA, E.L., April 1976, Radioactive Haste Repository Scudy Thermal Loading, submitted to the Atomic Energy of Canada, Limited.

RATICAN, J.L., 1976, Finice Element Methods of Thermal Analysis with Application to Wastc Canister Emplacentenc and Rock Fracturing, Review/Workshop on Radioactive Waste Disposal in Geological Formation: Deivei, C., PP. 31-37.

RATIGAN, J.L., 1977. Evaluation of Radioactive Waste Repository Parameters with Analytical Heat Transfer Solutions, to be subricted to the Office of Waste I solation, ORNt.

SCHNEIDER, K.J. and PLATT, A.M., editors, 1974, High Leval Radioactive Waste Management Alternatives, BNWL-1900.

VAN SAMbEEK; L.L., 1976, II Silu Experinent for Dume Salt, Review/Workshop on the Rock Mechanics Aspects of Radioactive Waste Disposal in Geologican Formations, Denver, Co., Pp. 67-74. 